(C) 2020

\title{
The effectiveness of the use of associative diazotrophs to increase the yield of spring triticale
}

\author{
Shakhovnina 0. \\ Institute of Agricultural Microbiology and Agroindustrial Manufacture of the NAAS \\ 97 Shevchenko Str., Chernihiv, 14027, Ukraine \\ e-mail: helenshah@ukr.net \\ ORCID: 0000-0001-9105-4116
}

Goal. To study the effectiveness of the use of associative Azospirillum brasilense diazotrophs 10/1 to increase the yield and improve grain quality of spring triticale. Methods. Microbiology, gas chromatography, field experiment, and statistical. The objects of study — plants of spring triticale of varieties Oberig Kharkivskii, the strain of associative nitrogen-fixing bacteria Azospirillum brasilense 10/1. Field experiments were carried out in conditions of Ukrainian Polissia (Institute of Agricultural Microbiology and Agroindustrial Manufacture, NAAS, Chernihiv). The inoculation of seeds of triticale was carried out with 3-days culture of bacteria A. brasilense $10 / 1$ for $2 \mathrm{~h}$ before seeding at the rate of $200-300$ thousand bacterial cells per seed. Processing of experimental data was performed using the computer program Microsoft Office Excel. Results. It is established that the strain $A$. brasilense 10/1 positively influenced the growth and development of spring triticale due to improved nitrogen nutrition of plants and the ability to produce growth-stimulation substances. Use of the strain A. brasilense $10 / 1$ for preplant bacterization of seeds triticale provided the increase in crop yield by $0.5 \mathrm{t} / \mathrm{ha}$, or of $16.39 \%$ compared to control. Positive influence is revealed on a mass of grains in one ear and weight of 1000 grains. These indicators increased in the variant with inoculation on average on 16.8 and $11.9 \%$, respectively. Also by inoculation of spring triticale with a promising strain of $A$. brasilense $10 / 1$ the protein content in the grain increased to $14.06 \%$, wet gluten - to the 35,17 , full-scale mass of grain increased by $7.3 \%$. Conclusions. Taking into account the positive effect of associative nitrogen-fixing bacteria $A$. brasilense 10/1 on the growth and development of triticale plants, perspective variant is the creation of a biological product based on the strain for increasing the yield and improving the quality of the resulting products.

Key words: Azospirillum brasilense, nitrogen-fixation, inoculation, biological preparation, structural indicators of the crop.

DOI: https://doi.org/10.31073/agrovisnyk202007-03

Triticale was first selected in the late nineteenth century in order to combine the best qualities of wheat and rye [1]. This crop exceeds both parent plants in a number of key features (yield, nutritional and biological value), and in terms of resistance to adverse weather conditions and disease, significantly exceeds wheat and is not inferior to rye [2,3]. Due to the larger number of grains in the ear, triticale forms a much higher productivity compared to wheat [1]. The plant is widely applied in the national economy as a forage, food and fodder crop [4, 5].

Today, triticale is successfully grown in many countries on an area over 4 million hectares, and world triticale grain production is over 17 million tons. In Ukraine, triticale sown areas reach 100,000 hectares annually [6, 7]. It is known that there is a direct relationship between the level of agrochemicals and the gross harvest of agricultural products [8, 9]. However, in Ukraine there is a negative balance of humus and nutrients [10]. Triticale belongs to the crops that are undemanding to soil fertility, but depends on the level of mineral nutrition, which significantly affects the formation of the productivity of their agrocenoses [1, 11]. Price escalation for mineral fertilizers necessitate the search for alternative sources of plant nutrition. One of the areas of environmentally friendly agriculture is the use of microbial preparations that have a positive effect on plant growth and development, as well as soil fertility [12-14].

Fixation of molecular nitrogen in the atmosphere is one of the most important biochemical processes, which significantly affects soil fertility and supply of plants with biological nitrogen [13-15]. One of the most active associative diazotrophs are representatives of the genus Azospirillum, which form effective associations with plants of wheat, rye, barley, buckwheat, etc. and are successfully used as bioagents of microbial preparations to increase the yield of above crops [14].

Considering the above, the objective of our research was to study the efficiency of the use of associative diazotrophs Azospirillum brasilense 10/1 to increase yields and improve quality of spring triticale grain.

Materials and methods. The objects of study were spring triticale Oberih Kharkivskyi cultivar, a strain of associative nitrogen-fixing bacteria Azospirillum brasilense 10/1 [16], selected by analytical selection as promising for inoculation of spring triticale.

Field experiments were conducted in the conditions of Polissia of Ukraine (Institute of Agricultural Microbiology and Agroindustrial Manufacture of NAAS, Chernihiv) on leached chernozem $(\mathrm{pH}-6.0$; humus content $-3.5 \%$; 
easily hydrolysed nitrogen (according to Cornfield) - $95 \mathrm{mg}$; mobile forms of phosphorus $\left(\mathrm{P}_{2} \mathrm{O}_{5}\right)$ (according to Kirsanov) - $251 \mathrm{mg}$; exchangeable potassium $\left(\mathrm{K}_{2} \mathrm{O}\right)$ (according to Kirsanov) - $108 \mathrm{mg}$ per $1 \mathrm{~kg}$ ).

The sowing rate of triticale is 5 million similar seeds per hectare. Method of sowing - narrow-row, with a row spacing of $15 \mathrm{~cm}$. The size of the experimental plot is $8 \mathrm{~m}^{2}$, the size of the accounting plot is $1 \mathrm{~m}^{2}$, the repetition is fourfold, the placement of plots is randomized. Seed inoculation was performed with a three-day culture of $A$. brasilense 10/1 bacteria two hours before sowing at the rate of 200-300 thousand bacterial cells per seed.

Potential nitrogenase activity on washed roots of triticale plants was determined by acetylene-ethylene method using gas chromatograph Chrom-4 [17].

Harvesting and accounting was performed by the direct method (weighing products from the accounting area). In order to study the structural parameters of the spring triticale crop, 100 typical plants were selected from each variant. Plant height, ear length, number and weight of grains in the ear, weight of 1,000 grains were determined [18].

The content of nitrogen, phosphorus and potassium, protein and raw fibres in the grain was determined using an infrared spectrophotometer IKS-4250 in National Scientific Centre "Institute of Soil Science and Agrochemistry named after O. N. Sokolovsky".

The ability of azospirilla to produce physiologically active substances has been shown by bioassays [19].

The experimental data were processed using the computer program Microsoft Office Excel.

Results and discussion. Introduction of associative nitrogen fixers in the root zone allows not only to improve nitrogen nutrition of plants by fixing atmospheric nitrogen and increasing the utilization rate of soil mineral nitrogen, but also provides a diverse positive effect of microorganisms on the plant, namely synthesis of biologically active substances, in particular phytohormones, stimulation of growth and development of the root system, lateral roots and root hairs [14].

Long-term studies of potential nitrogenase activity on washed roots of triticale plants in the field conditions showed that a promising strain of nitrogen-fixing bacteria A. brasilense 10/1 contributed to an increase in PNA (potential nitrogenase activity) more than twice, compared with the control variant.

Ability of $A$. brasilense 10/1 to produce growth stimulating substances has been shown on shoots of spring triticale Oberih Kharkivskyi cultivar (Fig.).

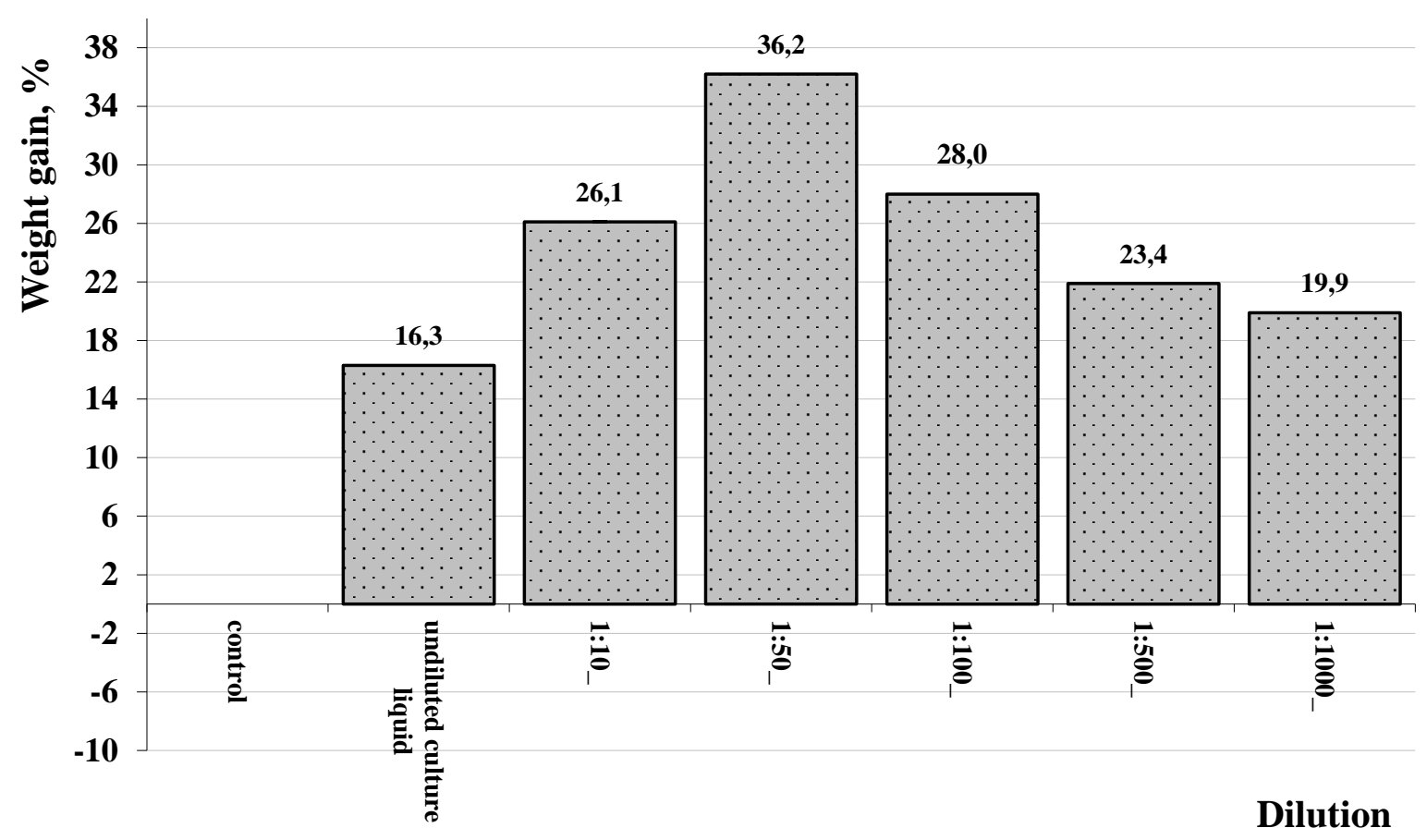

\footnotetext{
Gain of dry aboveground weight of spring triticale shoots of Oberih Kharkivskyi cultivar after treatment with culture liquid of $A$. brasilense 10/1 (laboratory experiment)
}

As evidenced by the data shown in Fig., the most significant increase in dry aboveground weight of shoots compared to control (seed treatment with sterile water) was registered after dilution of the culture liquid of the strain in a ratio of $1: 50$ and amounted to $36.2 \%$. Further dilution of the culture liquid was accompanied by a decrease in weight gain.

Analysis of the results of field experiments showed a stable probable increase in yield of spring triticale from pre-sowing inoculation of seeds with $A$. brasilense $10 / 1$, which averaged 0.5 t/ha or $16.39 \%$ to control. 
The structural analysis of the yield showed that pre-sowing inoculation of spring triticale with $A$. brasilense 10/1 contributed to an increase in plant height by an average of $1.7 \mathrm{~cm}$ (Table 1).

1. Structural parameters of the yield of spring triticale after inoculation with $A$. brasilense 10/1, average 3-year data $(M \pm m, n=3)$

\begin{tabular}{|c|c|c|}
\hline Parameters & Without inoculation (control) & $\begin{array}{c}\text { Inoculation with } \text { A. brasilense } \\
10 / 1\end{array}$ \\
\hline Height of triticale plant, $\mathrm{cm}$ & $93.56 \pm 5.57$ & $95.26 \pm 5.85$ \\
\hline $\begin{array}{c}\text { Number of grains per one ear, } \\
\text { pcs }\end{array}$ & $36.29 \pm 0.64$ & $38.24 \pm 1.90$ \\
\hline Weight of grains per one ear, $\mathrm{g}$ & $1.25 \pm 0.02$ & $1.46 \pm 0.06$ \\
\hline Weight of 1,000 grains, $\mathrm{g}$ & $35.07 \pm 0.51$ & $39.24 \pm 0.56$ \\
\hline
\end{tabular}

The most determinative elements for the formation of spring triticale yield are such elements of yield structure as the number and weight of grains from per ear and weight of 1,000 grains [20]. Their level predominantly depends on ecological and geographical conditions, weather and climatic factors of the growing season, quality and timeliness of agro-technological measures in contrast to the length of the ear and the number of spikelets in the ear, which are considered stable and depend on the properties of a particular genotype [21].

The results of the study of the number of grains in the ear of spring triticale suggest a tendency to increase this parameter after inoculation with $A$. brasilense 10/1. Regarding the weight of grains per ear and weight of 1,000 grains, these parameters increased in the variant with inoculation by an average of 16.8 and $11.9 \%$, respectively.

The peculiarity of the action of biopreparations with nitrogen-fixing microorganisms as bioagents is the additional supply of macronutrients to the reproductive organs of plants and a proportional increase in their weight, which results in increase of grain yield and its quality parameters. The results of our studies indicate an increase in the nitrogen content in the grain of triticale (Table 2).

2. Content of macronutrients in grain of spring triticale Oberih Kharkivskyi cultivar after seed inoculation with active strain $A$. brasilense 10/1

\begin{tabular}{|c|c|c|c|}
\hline \multirow{2}{*}{ Variants of experiment } & \multicolumn{3}{|c|}{ Content, \% } \\
\cline { 2 - 4 } & Nitrogen & Phosphorus & Potassium \\
\hline $\begin{array}{c}\text { Without inoculation } \\
\text { (control) }\end{array}$ & $2.12 \pm 0.07$ & $0.87 \pm 0.03$ & $0.25 \pm 0.01$ \\
\hline $\begin{array}{c}\text { Inoculation with } \\
\text { A. brasilense 10/1 }\end{array}$ & $2.25 \pm 0.09$ & $1.09 \pm 0.03$ & $0.30 \pm 0.01$ \\
\hline
\end{tabular}

Grain quality is an integrated parameter of variety interaction, natural and climatic features, agrotechnical, organizational and economic conditions of triticale cultivation. After inoculation of spring triticale with a promising strain A. brasilense 10/1, the protein content in the grain increased to $14.06 \%$, raw fibre - up to $35.17 \%$, bushel weight of the grain increased by $7.3 \%$ (Table 3 ).

3. Quality of grain of spring triticale Oberih Kharkivskyi cultivar after seed inoculation with active strain A. brasilense 10/1

\begin{tabular}{|c|c|c|c|}
\hline $\begin{array}{c}\text { Variants of } \\
\text { experiment }\end{array}$ & Content of protein, \% & $\begin{array}{c}\text { Content of raw fibre, } \\
\%\end{array}$ & $\begin{array}{c}\text { Bushel weight of } \\
\text { grain, } \mathrm{g} / \mathrm{L}\end{array}$ \\
\hline $\begin{array}{c}\text { Without inoculation } \\
\text { (control) }\end{array}$ & $12.35 \pm 0.37$ & $29.00 \pm 0.87$ & $678.16 \pm 20.34$ \\
\hline $\begin{array}{c}\text { Inoculation with } \\
\text { A. brasilense 10/1 }\end{array}$ & $14.06 \pm 0.42$ & $35.17 \pm 1.05$ & $735.54 \pm 22.05$ \\
\hline
\end{tabular}

\section{Conclusion}

It was established that the strain A. brasilense 10/1 influences the growth and development of triticale plants both as a diazotroph and as a producer of growth stimulating substances.

According to the results of three-year field studies, the increase in yield after pre-sowing inoculation of seeds of spring triticale with A. brasilense $10 / 1$ averaged 0.5 t/ha or $16.39 \%$ compared to control. 
Bacterization of seeds with A. brasilense 10/1 has a positive effect on the structure of the triticale crop: there is a tendency to increase the number of grains per ear, weight gain of grains in the ear, increase in weight of 1,000 grains.

Inoculation with associative nitrogen-fixing bacteria A. brasilense $10 / 1$ also provides an increase in the content of macronutrients and improves the quality of grain of spring triticale.

Considering the positive influence of the studied strain on the yield of spring triticale and the quality of the product, it is promising to create a biopreparation based on A. brasilense 10/1.

\section{References}

1. Shulydin, A. F. (1981). Tritikale - novaya zernovaya $i$ kormovaya kultura [Triticale - new grain and fodder crop]. Kyev: Urozhay. [In Russian].

2. Bilitiuk, A. P., Hirko, V. S., Kalenska, S. M., \& Andrushkiv, M. I. (2004). Trytykale v Ukraini [Triticale in Ukraine]. Monograph. Kyiv. [In Ukrainian].

3. Riabchun, V. K., Shatokhin, V. I., Lisnychyi, V. A., \& Kapustina, T. B. (2007). Yare trytykale dlia stabilnoho vyrobnytstva zerna [Spring triticale for stable production of grains]. Kharkiv: Plant Production Institute named after V. Ya. Yuriev. [In Ukrainian].

4. Djekic, V. R., Mitrovic, S., Milovanovic, M. S., Djuric, N., Kresovic, B., Tapanarova, A., Djermanovic, V., \& Mitrovic, M. (2011). Implementation of triticale in nutrition of non-ruminant animals. African Journal of Biotechnology, 10, 5697-5704. https://doi.org/10.5897/AJB10.986.

5. Hrib, S. I., Bulavina, T. M., Bushtevich, V. N., \& Khatetovskii, Yu. F. (2009). Tritikale - tsennaya zernofurazhnaya kultura [Triticale - a valuable fodder grain]. Bulletin of Seed Production in CIS countries, 1, 1719. [In Russian].

6. Rybalka, O. I., Morhun, V. V., Morhun, B. V., \& Pochynok, V. M. (2015). Ahronomichnyi potentsial i perspektyvy trytykale [Agronomic potential and prospects of triticale]. Physiology of plants and genetics, 47(2), 95-111. [In Ukrainian].

7. Kalenska, S. M. (2017). Trytykale - potentsial ta upravlinnia yoho realizatsiieiu [Triticale - potential and management of its implementation]. In Trytykale - kultura XXI storichchia [Triticale $-21^{\text {st }}$ century crop]. Kharkiv, Ukraine. [In Ukrainian].

8. Shevchuk, M. I, Veremeienko, S. I., \& Lopushniak, V. I. (2012) Dobryva ta yikh vplyv na bioproduktyvnist gruntu [Fertilizers and their influence on soil bioproductivity]. Ahrokhimiia: pidruchnyk [Agrochemistry: text book]. Lutsk: Nadstyria. [In Ukrainian].

9. Baliuk, S. A., Miroshnychenko, M. M., Berdnikov, O. M., Vozhehov, S. H., Havryliuk, V. A. (Baliuk, S. A., Miroshnychenko, M. M. (Eds.)). (2016). Systemy udobrennia silskohospodarskykh kultur u zemlerobstvi pochatku $X X I$ stolittia [System of fertilization of crops in agriculture in the early $21^{\text {st }}$ century]. Monograph. Kyiv: Alfa-Steviia. [In Ukrainian].

10. Yatsuk, I. P., Panasenko, V. M., \& Zhylkin, V. A. (2015). Okhorona gruntiv yak peredumova rozvytku i zberezhennia ahrarnoho sektoru Ukrainy [Protection of soils as a precondition of development and maintenance of agrarian sector in Ukraine]. In Okhorona gruntiv ta pidvyshchennia yikh rodiuchosti [Protection of soils and improvement of their fertility]. Odesa, Ukraine. Kyiv: Vik-Print. [In Ukrainian].

11. Sukhomud, O. H., \& Liubych, V. V. (2013). Vmist kleikovyny v zerni trytykale yaroho zalezhno vid rivnia azotnoho zhyvlennia [Content of fibres in spring triticale grain depending on the level of nitrogen nutrition]. Scientific reports of the National University of Life and Environmental Sciences, 2 (38). [In Ukrainian]. Retrieved from: http://www.nbuv.gov.ua/ejournals/Nd/2013_2/13sog.pdf.

12. Volkohon, V. V., Zaryshniak, A. S., Pylypenko, L. A., Rudiuk, A. M., Dyshliuk, V. le., ... Marchuk, P. A. (Volkohon, V. V. (Ed.)). (2015). Mikrobni preparaty $v$ suchasnykh ahrarnykh tekhnolohiiakh (naukovo-praktychni rekomendatsii) [Microbial preparations in modern agrarian technologies (scientific and practical guidelines)]. Kyiv. [In Ukrainian].

13. Patyka, V. P., Kots, S. Ya., Volkohon, V. V., Sherstoboieva, O. V., Melnychuk, T.M., Kalinichenko, A. V., Hrynyk, I. V. (Patyka, V. P. (Ed.)). (2003). Biolohichnyi azot [Biological nitrogen] Kyiv: Svit. [In Ukrainian].

14. Kots, S. Ya., Morhun, V. V., Patyka, V. F., Petrichenko, V. F., Nadkernichnaya, Ye. V., \& Kirichenko, Ye. V. (2014). Assotsiativnaya azotfiksatsiya [Associative nitrogen fixation]. Biologicheskaya fiksatsiya azota [Biological nitrogen fixation]. Monograph in 4 volumes. (Vol. 4). Kiev: Lohos. [In Russian].

15. Andreyuk, Ye. I., Antipchuk, A. F., Babayants, O. V., Belyavskaya, L. A., \& Brovko, I. S. (lutinskaya G. A., Ponomarenko S. P. (Eds.)). (2010). Bioregulyatsiya mikrobno-rastitelnykh sistem. [Bioregulation of microbial-plant systems]. Monograph. Kiev: Nichlava. [In Russian].

16. Nadkernychna, O. V., Shakhovnina, O. O., Ushakova, M. A. Patent no. 104212 C2 Ukraine IPC C12N 1/20 (2006.01) C12R (2006.01) C05F11/08 (2006.01). Shtam bakterii Azospirillum brasilense dlia inokuliatsii nasinnia trytykale yaroho [Bacterial strain Azospirillum brasilense for inoculation of spring triticale seeds]; Applicant and Patent Attorney Institute of Agricultural microbiology and Agroindustrial Manufacture of NAAS of Ukraine. no. a 2012 03817; stated on 29.03.2012; posted by 10.01.2014. 3 p. [In Ukrainian].

17. Hardy, R. W. F., Holsten, R. D., Jackson, E. K., \& Burns, R. C. (1968). The acetylene-ethylene assay for N2-fixation: Laboratory and field evaluation. Plant Physiol., 43(8), 1185-1207.

18. Hrytsaienko, Z. M., Hrytsaienko, A. O., \& Karpenko, V. P. (2003). Metody biolohichnykh ta ahrokhimichnykh doslidzhen roslyn ta gruntiv [Methods of biological and agrochemical studies of plans and soils]. Kyiv: Nichlava. [In Ukrainian]. 
19. Vozniakovskaia, Yu. M. (Ed.) (1982). Nekotorye novye metody kolichestvennogo ucheta pochvennykh mikroorganizmov i izuchenie ikh svoystv [Some new methods of quantitative accounting of soil microorganisms and study of their properties]. Guidelines. Leningrad. [In Russian].

20. Lopushniak, V., \& Avhustynovych, M. (2013). Formuvannia struktury vrozhaiu trytikale yaroho za riznykh system udobrennia [Formation of the structure of spring triticale yield under different fertilization systems]. Bulletin of Lviv National Agrarian University, 17(1), 211-217. [In Ukrainian].

21. Pysarenko, P. V., Moskalets, V. V., Moskalets, T. Z., \& Moskalets, V. I. (2013). Vplyv biolohizovanoi ahrotekhnolohii vyroshchuvannia trytykale ozymoho na elementy struktury urozhainosti zerna [Influence of biologized agrotechnology of growing spring triticale on the elements of structure of grain yield]. Bulletin of Poltava State Agrarian Academy, 2, 10-14. [In Ukrainian]. 